\title{
Tai chi Effects on Nursing Diagnosis
}

\section{Milaol Medo}

Department of Nursing, University of Granada, Calle Real de Cartuja, 36-38, 18071 Granada, Spain

\begin{abstract}
Aging is the physiological process, which starts in the conception producing characteristic changes to all the species during their life cycle. In the last decades of life, those changes produce a limit on adaptations of organisms in relation to their environment. Those problems can be processed by three diagnoses -Impaired physical mobility, sedentary lifestyle and impaired memory. The methodology proposes 18 outcomes included in the last version of NOC. Those outcomes are used to assess the intervention of tai chi during the four months developed with a group of 19 women older than 55 years which they presented theses diagnoses. The correlations were studied with Pearson and Spearman. The difference of variables between first sample and the last sample, which were more significant in relation to sedentary lifestyle. This is a pilot experience but it is the first step to the challenge of making standard instruments and scales for the outcomes of the nursing methodology.
\end{abstract}

\section{Introduction}

Aging is the physiological process, which starts in the conception producing characteristic changes to all the species during their life cycle. In the last decades of life, those changes produce a limit on adaptations of organisms in relation to their environment. The rate that these changes are developing on the different organs on the same person or different people, they are not the same [1]. From the point of view of the nursing diagnoses, which are defined as "A clinical judgement about the individual, the family or the community answers to real or potential life process, which provide the base to choose the interventions to reach results that the professional nurse is responsible" [2]. In aging the more frequent health problems are the mobility, the energy and the memory and also others, like sleep, pain or social isolation [3]. Those problems can be processed by three diagnoses -Impaired physical mobility, sedentary lifestyle and impaired memory.

Impaired physical mobility is defined by NANDA as "A state in which the individual experiences a limitation of ability for independent physical movement". This limitation is produced by osteo-muscular diseases associated directly or indirectly with the aging, triggering walking and balance disorder that results in an exacerbation of the risk of falls [4].

Impaired memory is defined as "An inability to remember bits of information or behavioural skills" The subject older than 55 years perceive their memory more impaired than when they were young [5], but in recent studies it has been demonstrated that the "regeneration" of lost brain cells is able due to learning, a healthy mental life and exercise [6].

The sedentary lifestyle is defined as "A mode of living in which a person does not engage in sufficient physical activity or exercise for what is generally considered healthy living" The sedentary lifestyle joint to aging are two of the most important risk factors of cardiovascular disease [7].

The physical activity, specifically Tai chi, is a therapy of physical activity spread around the world for palliating and slowing down the effects produced degenerative process. The Tai chi has been studied on different health problems getting positive results over the blood pressure in sedentary patients [8], or over the balance and flexibility $[9,10]$ and over the mental capacity $[11]$.

\section{Outcomes}

Determine the incidence on the nursing diagnoses "Impaired physical mobility", "sedentary lifestyle" and "impaired memory" with a programme of Tai chi over 16 weeks on women older than 55 years.

\section{Materials \& Methods}

Through the process of Nursing Diagnoses (NANDA-I) Outcomes (NOC) and Interventions (NIC) with the book of NANDA NOC NIC linkage, the methodology propose 18 outcomes included in the last version of NOC [12]. Those outcomes are used to assess the intervention of tai chi during the four months developed with a group of 19 women older than 55 years which they presented theses diagnoses (Table-1). The independent variable was the Tai chi, which twice a week during sixteen weeks the group used to work with a qualified tutor with a physical activity plan. The indicators used are the dependent variable:

\section{Results}

Three samples were taken: before the intervention, after two months and after 4 months. The results are expressed as mean and standard deviation. The effect of the treatment of the analysed variables was performed with student's t-test and Wilcoxon. The correlations were studied with Pearson and Spearman. The difference of variables between first sample and the last sample, which were more significant in relation to Sedentary lifestyle, were the systolic blood pressure 7,36 $\pm 19,10$ (Sig. 0,002), BMI 0,69 $\pm 0,58$ (Sig. 0,000) and the Barthel's scale $95,53 \pm 6,867$ vs $99,21 \pm 1,873$, (Sig. 0,018).

The difference of variables between first sample and the last sample, which were more significant in relation to impaired physical mobility, were MII $-0,684 \pm 0,671$ (Sig. 0,000), knee extension 188,16 $\pm 5,58$ vs $181,58 \pm 2,38$ (Sig. 0,001 ), knee flexion $250,26 \pm 10,20$ vs 275,26 $\pm 13,89$ (Sig. 0,000), represented on Figure 1, Timed up and go test $11,00 \pm 3,41$ and balance on one foot $8,11 \pm 5,64$ vs 2,47 $\pm 2,89$ (Sig. $0,000)$.

"Corresponding Author: Dr. Milaol Medo, Department of Nursing, University of Granada,, Calle Real de Cartuja, 36-38, 18071 Granada, Spain; E-mail: milaolmedo@ugr.es

Citation: Medo M (2015) Tai chi Effects on Nursing Diagnosis. Int J Nurs Clin Pract 2: 122. doi: http://dx.doi.org/10.15344/2394-4978/2015/122

Copyright: ( 2015 Medo. This is an open-access article distributed under the terms of the Creative Commons Attribution License, which permits unrestricted use, distribution, and reproduction in any medium, provided the original author and source are credited. 


\begin{tabular}{|c|c|c|c|c|}
\hline NANDA & NOC & Code & Outcome & Test \\
\hline \multirow[t]{5}{*}{ Sedentary lifestyle } & \multirow[t]{3}{*}{ Physical fitness } & 200409 & Body mass Index & Body mass index (BMI) \\
\hline & & 200411 & Blood Pressure & $\begin{array}{l}\text { Systolic blood pressure } \\
\text { Diastolic blood pressure }\end{array}$ \\
\hline & & 200414 & Heart rate & Pulse \\
\hline & \multirow[t]{2}{*}{ Endurance } & 000101 & Performance of usual routine & Barthel's test \\
\hline & & 000112 & Blood oxygen level with activity & Saturation of $\mathrm{O} 2$ \\
\hline \multirow[t]{6}{*}{ Impaired physical mobility } & \multirow[t]{2}{*}{ Balance } & 020203 & Maintains balance while walking & Step up and go Test \\
\hline & & 020209 & Maintains balance while standing on one foot & Balance on one foot \\
\hline & \multirow[t]{2}{*}{ Joint movement } & 020615 & Knee (right) & \multirow[t]{2}{*}{ Goniometry } \\
\hline & & 020616 & Knee (Left) & \\
\hline & \multirow{2}{*}{$\begin{array}{l}\text { Coordinated } \\
\text { movement }\end{array}$} & 021202 & Muscle tone & Hand Dynamometer \\
\hline & & 021208 & Muscle tension & Muscular Mass Index \\
\hline \multirow[t]{3}{*}{ Impaired memory } & \multirow[t]{3}{*}{ Memory } & 090801 & Recalls immediate information accurately & \multirow[t]{3}{*}{ Test of RAVLT } \\
\hline & & 090802 & Recalls recent information accurately & \\
\hline & & 090803 & Recalls remote information accurately & \\
\hline
\end{tabular}

Table 1. Diagnoses (NANDA,) NOC, Outcomes and Tests.

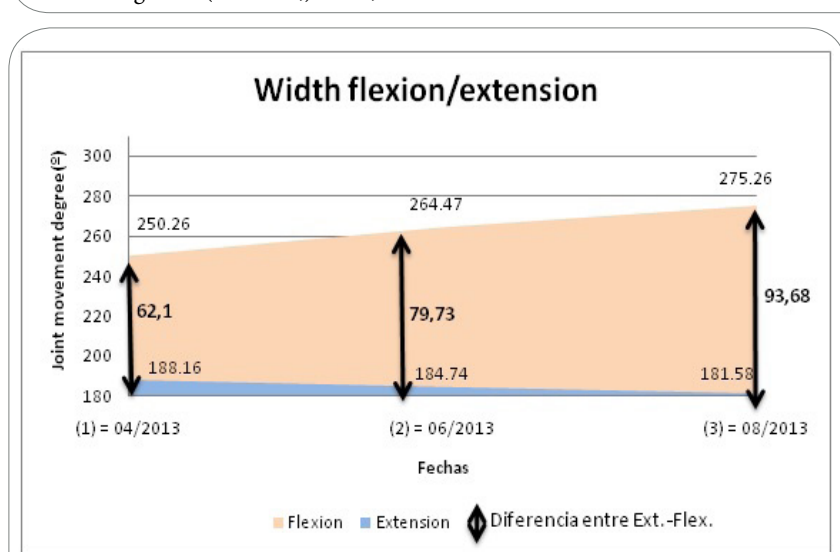

Figure 1: Knee's width over longitudinal axis.

The difference of variables between first sample and the last sample (Figure 2), which were more significant in relation to impaired memory, were Trial 1-5 -2,78 $\pm 1,78$ (Sig. 0,001) Deferred 5,84 $\pm 1,97$ vs 7,53 $\pm 2,95$ (Sig. 0,004) Recognition $-2,00 \pm 2,05$ (Sig. 0,000).

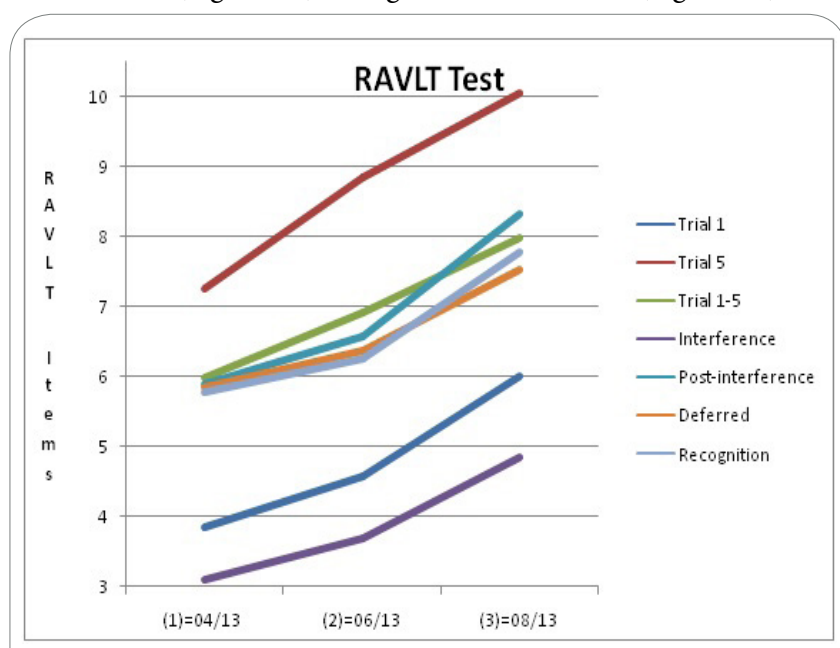

Figure 2: Mean differences on RAVLT items.

\section{Discussion}

Subjects who practise Tai chi get an improvement in all the areas of the biopsychosocial sphere, contributing in their quality of life. The biggest aspect in the physical mobility is the improvement of balance, Valero Serrano (2010) [13] got proportional results to these results, with the difference that their study was longer than four weeks. Cuenca del moral, R. (2012) [14] concluded an improvement in the balance on one foot, decreasing the number of falls to 2.04 to 0.4. Wan C.'s study (2011) [15] stands out the flexibility on the knee on rheumatic patients with nearly a full recovery of the mobility. The outcome more relevant in relation to the sedentary lifestyle was the performance of usual routine measured with the Barthel's scale. Chen's study (2008) [16] shows similar results in relation to the upgrading that his subjects could get due to his patients were more dependent with the self-care than the subjects of this study who could assist to the class by their selves. About the impaired memory, the revision about cognitive results shows an important improvement like in the study of Yukai Chang (2010) [17], in spite he usedanother test, an MMSE. He demonstrated the improvement of the cognitive function in elderly patients. The studies shorter than 16 weeks did not show significant results.

\section{Conclusion}

We have demonstrated through this study that to practise Tai chi produces an improvement on the physical mobility with positive results on the balance and flexibility, that the sedentary lifestyle develop positive changes on the performance of usual routine, making to the subjects more independent with the self-care. Results are very hopeful on the memory that arises from the socialization and from the learning challenge. This is a pilot experience but it is the first step to the challenge of making standard instruments and scales for the outcomes of the nursing methodology.

\section{Competing Interests}

The authors declare that they have no competing interests.

\section{References}

1. Planificacion y organizacion de los serviciosgeriatricos. Organizacion Mundial de la saludserie de informestecnicos No: 548. OMS Ginebra, 1974. 
2. North American Nursing Diagnosis Association, NANDA. Diagnosticos enfermeros [de la] NANDA: definiciones y clasificación, 2005-2006 : Elsevier Espana, 2005.

3. Orueta Sanchez R, Rodriguez de Coso A, Carmona de la Morena, Javier Moreno Alvarez-Vijande A, et al. (2008) Anciano Fragil y Calidad de Vida. RevistaClinica de Medicina de Familia 2: 101-105.

4. Durán de la Fuente, Irma Erika, Morales Razo P, Rivas Ruíz R (2009) Caídasen el anciano. Revista de la Facultad de Medicina 50: 6.

5. Angrino SO, Espinosa LA, Caicedo AM (2005) memoria y metamemoria en adultos mayores estado de la cuestión. Red Acta Colombiana de Psicología 8: 2.

6. Fred HG ((2003) "Regeneración cerebral" Manipulación cerebral. Investigación y ciencia.

7. Roberto E (2005) "Actividadfísica. Un eficiente y olvidadoelemento de la prevención cardiovascular, desde la infancia hasta la vejez." Revista Española de Cardiología 58: 887-890.

8. Young DR, Appel LJ, Jee S, Miller ER (1999) The effects of aerobic exercise and Tai Chi on blood pressure in older people: results of a randomized trial. J Am Geriatr Soc 47: 277-284.

9. Au-Yeung SS, Hui-Chan CW, Tang JC. (2009) Short-form Tai Chi improves standing balance of people with chronic stroke. Neurorehabil Neural Repair 23: 515-522.

10. Hong Y, Li JX, Robinson PD (2000) Balance control, flexibility, and cardiorespiratory fitness among older Tai Chi practitioners. Br J Sports Med 34: 29-34.

11. Mortimer JA, Ding D, Borenstein AR, et al. Changes in brain volume and cognition in a randomized trial of exercise and social interaction in a community-based sample of non-demented Chinese elders. J Alzheimers Dis 30: 757-766.

12. Moorhead S, Johnson M, Maas ML, Swanson E (2009) Clasificación de resultados de enfermeria (NOC): Elsevier Health Sciences.

13. Serrano BV, Morales PF, Martínez FG, León Belmar Jd, Quijada Rodríguez JL (2010) La práctica del Tai Chi previene las caídas en el Anciano Institucionalizado: Un Ensayo Clínico. Revista Clínica de Medicina de Familia 3:1.

14. Cuenca del Moral R, Munoz Cobos F, Xia Ye SY, Ramirez Aliaga M, Vallejo Canete $V$ et al. (2012) Impacto de una intervención multifactorial en personas mayores con riesgo de caídas. Efecto diferencial de la práctica del Tai Chi. Med fam Andal 13: 17-27.

15. Wang C (2011) Tai chi and rheumatic diseases. Rheum Dis Clin North Am 37: $19-32$.

16. Chen KM, Lin JN, Lin HS, Wu HC, Chen WT, et al. (2008) The effects of a Simplified Tai-Chi Exercise Program (STEP) on the physical health of older adults living in long-term care facilities: a single group design with multiple time points. Int J Nurs Stud 45: 501-507.

17. Chang YK, Nien YH, Tsai CL, Etnier JL (2010) Physical activity and cognition in older adults: the potential of Tai Chi Chuan. J Aging Phys Act 18: $451-472$. 